\title{
Nest site location and nest success in the hawksbill turtle Eretmochelys imbricata in Barbados, West Indies
}

\author{
J. A. Horrocks ${ }^{1,2}$, N. McA. Scott ${ }^{1}$ \\ ${ }^{1}$ Department of Biology, University of the West Indies, Cave Hill, Barbados \\ ${ }^{2}$ Bellairs Research Institute of McGill University, St. James, Barbados
}

\begin{abstract}
Effects of nest location on nest success of hawksbill turtles Eretmochelys imbricata in Barbados were investigated. Hawksbills nested more frequently on west coast than south and east coast beaches, suggesting that they prefer beaches with lower wave energy and steeper beach slopes. Sheltered beaches may be preferred because of the mechanical difficulties and energetic costs of moving onto and off high energy beaches. Hawksbills nested at specific elevations above mean sea level. Elevation was controlled by altering the distance travelled inland on beaches of different slopes. Steeper beaches may therefore be preferred because gravid females and hatchlings may have lower travel costs and lower predation risk. Nest success (number of hatchlings emerging from a nest) was highest from nests closest to mean elevation and declined at higher and lower elevations. This was because emergence success (\% eggs laid that emerge as hatchlings) was highest near mean elevation. The high emergence success was due both to a high hatching success (\% eggs hatching) and high escape success (\% hatchlings escaping from the nest). Emergence success decreased with increasing compaction, due both to an increase in the percentage of dead embryos in nests (late pre-hatching mortality) and a decrease in escape success of hatchlings. Hawksbills preferred to nest amongst vegetation. Vegetated nest sites were less compacted than non-vegetated, and had higher escape success. Hatchling sex ratios were biased towards males on cooler south coast beaches and towards females on warmer west coast beaches. Coastal development may constrain the recovery of hawksbill populations in the Caribbean by forcing females to nest at lower elevations and by increasing compaction through heavy recreational use of beaches and clearance of beach vegetation.
\end{abstract}

\section{INTRODUCTION}

The hawksbill sea turtle Eretmochelys imbricata is a circumtropical species inhabiting coastal reefs, bays, estuaries and lagoons in the tropical and subtropical Atlantic, Pacific and Indian oceans (Witzell 1983). Hawksbills have been exploited for their shells, and less widely for their meat and eggs, for thousands of years. They are now listed in Appendix 1 of the Convention on International Trade in Endangered Species of Wild Fauna and Flora (CITES) as threatened with extinction and subject to special trade restrictions. The hawksbill is the principal turtle species nesting and exploited in Barbados, the shell, meat and eggs all being utilised on the local market.

In most countries of the eastern Caribbean, including Barbados, fisheries legislation exists to protect turtles. Strict enforcement of the regulations could decrease fishing pressure on hawksbills, but environmental fac- tors on beaches might still constrain their recovery. Like most countries in the eastern Caribbean, Barbados is expanding its tourist industry. Since tourism-related development directly affects the beach zone, it may reduce the availability of suitable nesting sites for hawksbills, thereby jeopardising their nesting success throughout the eastern Caribbean.

Sea turtle nest success is believed to be influenced by a number of interacting ecological factors such as sand temperature, sand particle size, water content and salinity (Miller 1985). However, the tendency of hawksbills to nest singly and to lay several quite widely separated nests over an extended breeding season (Carr \& Stancyk 1975), rather than nesting in large numbers at known breeding beaches, has made studies of nest success difficult. For example, although it is known that hawksbills nest and are exploited on most of the islands in the eastern Caribbean, there is little information on their reproductive biology in the region 
(but see Witzell 1983, Richardson et al. 1989, Ryder et al. 1989).

The factors affecting nest site location and nest success of hawksbills are not known, and the effect of coastal development on nesting is therefore difficult to predict. Nest site location may not only affect nest success, but may also affect hatchling sex ratio, if sex determination is temperature-dependent in hawksbills as it is in other marine turtles (see Mrosovsky \& Yntema 1980, Limpus et al. 1983). In this study, we investigated the location of hawksbill nest sites in Barbados and the effects of nestsite characteristics on nest success and hatchling sex ratio, and comment on the implications of continuing coastal development for hawksbill nesting in Barbados.

\section{METHODS}

Prior to the 1987, 1988 and 1989 hawksbill breeding seasons, the Barbadian public was requested, through the various media, to telephone in information on all nesting activities observed (see Horrocks et al. 1989 for description of public education programme). The sites of all reported nestings were confirmed, and the locations of each nest recorded. A random sample $(n=32)$ of these nests was investigated to obtain information on nest characteristics and nest success. The distance of each nest above the high tide mark and the presence or absence of vegetation at the nest site were recorded. The slope of the beach was measured for each site (see Atherley 1987), and was used, along with the distance of the nest inland from the high tide mark, to calculate the elevation of each nest above mean sea level.

After hatching, the nests were excavated. The numbers of hatched and unhatched eggs, and the number of dead and moribund hatchlings remaining in each nest were recorded. Unhatched eggs were opened and classified as either undeveloped i.e. no discernable embryo (unfertilised or very early mortality) or as dead embryos (embryo clearly discernible). Clutch size was recorded for all nests. All freshly dead hatchlings (usually those that died from exhaustion following disorientation by lighting) were sexed histologically. To do this, the gonads were removed and preserved in $10 \%$ buffered formalin. They were subsequently embedded, sectioned and stained with hematoxylin and periodic Acid-Schiff Reaction (PAS) (Yntema \& Mrosovsky 1980).

Sand samples were taken at nest depth following hatching to obtain information on edaphic characteristics at nest sites. Particle size was obtained by shaking a known weight of oven-dried sand through Endicott sieves. The percent of the sample with particles $<425$ $\mu \mathrm{m}$ in diameter was used as the index of particle size. Water content was quantified by drying a known weight of sand at $120^{\circ} \mathrm{C}$ for $6 \mathrm{~h}$ and re-weighing. The weight loss was expressed as \% of original weight to give $\%$ water content of sand. Organic content was quantified by taking a known weight of dried sand from each site and ashing it in a muffle furnace for $7 \mathrm{~h}$ at $350^{\circ} \mathrm{C}$. Each sample was reweighed after cooling, and the weight loss was expressed as \% of the original weight to give \% organic content of the sand. Sand compaction was measured using an Eijkelkamp-Giesbeek penetrometer which measures penetration resistance through a semi-solid medium in newtons $\mathrm{cm}^{-2}$. At each nest site, readings were taken at 3 positions $0.5 \mathrm{~m}$ from the point of hatchling emergence from the nest, and a mean penetration resistance for each site was calculated. Finally, 4 temperature readings were taken between 14:00 and 16:00 h at nest depth at each site using a YSI 400 series thermistor. From these readings, a mean temperature for each nest site was calculated.

\section{RESULTS}

\section{Nest location}

\section{Variation between coasts}

There are no suitable nesting beaches on the north coast of Barbados (A to B; Fig. 1), and few on the southeast coast ( $C$ to $D$ ), where a suitable nesting

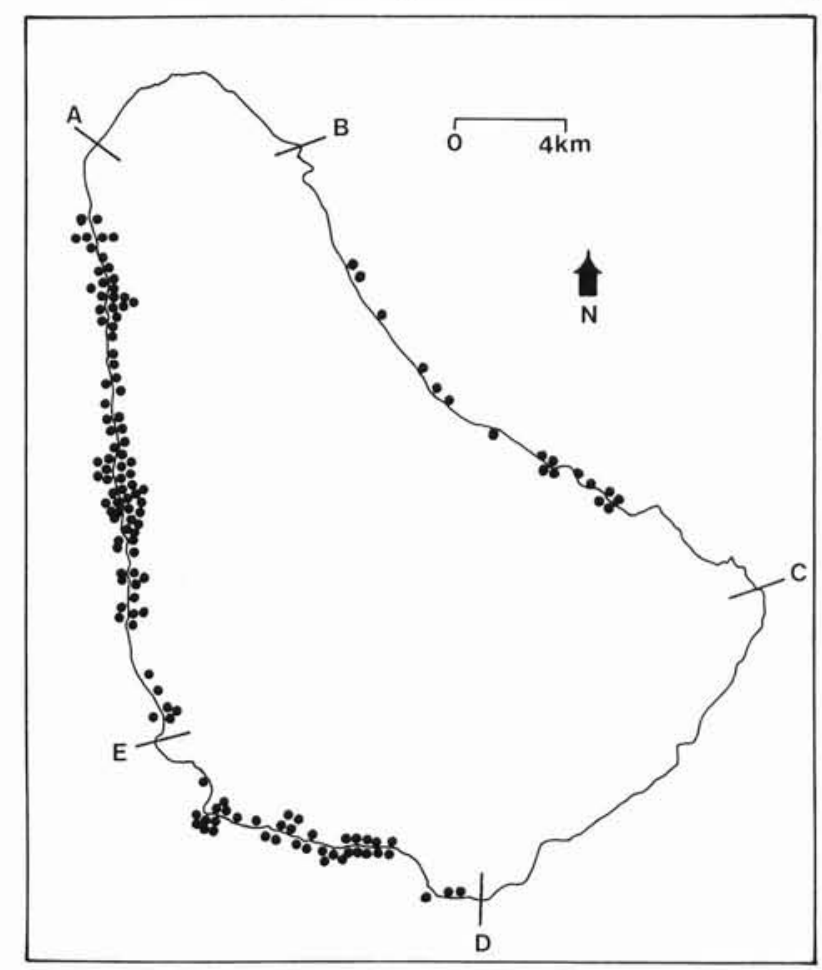

Fig. 1. Barbados, showing locations of hawksbill nests in 1987. 1988 and 1989 
Table 1. Eretmochelys imbricata. Number of nests of hawksbill turtles reported on the west, south and east coast beaches of Barbados in 1987, 1988, and 1989. Nests $\mathrm{km}^{-1}$ is the number of nests per kilometre of beach

\begin{tabular}{|c|c|c|c|c|c|c|c|c|c|}
\hline \multirow[t]{2}{*}{ Year } & \multicolumn{3}{|c|}{ West coast } & \multicolumn{3}{|c|}{ South coast } & \multicolumn{3}{|c|}{ East coast } \\
\hline & \# Nests & $\%$ Nests & Nests $\mathrm{km}^{-1}$ & \# Nests & $\%$ Nests & Nests $\mathrm{km}^{-1}$ & \# Nests & $\%$ Nests & Nests $\mathrm{km}^{-1}$ \\
\hline 1987 & 36 & 60.0 & 2.9 & 14 & 23.3 & 1.2 & 10 & 16.7 & 0.8 \\
\hline 1988 & 29 & 56.9 & 2.3 & 18 & 35.3 & 1.5 & 4 & 7.8 & 0.3 \\
\hline 1989 & 30 & 46.9 & 2.4 & 21 & 32.8 & 1.8 & 13 & 20.3 & 1.0 \\
\hline
\end{tabular}

beach is defined as one on which sand remains exposed at high tide. Consequently, only 3 nests were observed on these coasts during the 3 yr study period and it was therefore not possible to investigate nest success. The locations of the 60 hawksbill nests reported in 1987, 51 in 1988, and 64 in 1989 are shown in Fig. 1. In all 3 years, there were fewer nests on east coast beaches (B to $C_{i}$ Fig. 1) than on south coast beaches (D to $E_{;}$Fig. 1) and west coast beaches ( $E$ to $A$; Fig. 1, see Table 1). The difference in numbers of nests on the west, south and east coasts could result, not from preference by hawksbill for a particular coast, but from variation between coasts in the availability of suitable nesting beaches. There are $12.5 \mathrm{~km}$ of suitable nesting beaches on the west coast, $11.7 \mathrm{~km}$ on the south coast and $12.4 \mathrm{~km}$ on the east coast. However, in all 3 years, the number of nests per kilometre of beach was highest on the west coast and lowest on the east coast (Table 1). The data therefore suggest that hawksbills prefer to nest on west coast rather than south and east coast beaches.

Environmental characteristics of west, south and east coast beaches are shown in Table 2. The coasts differ significantly in all environmental characteristics meas-

Table 2. Environmental characteristics of west, south and east coast beaches. Means (standard deviations). - Significant differences between coasts (Kruskal-Wallis; $\mathrm{p}<0.05$ )

\begin{tabular}{|c|c|c|c|}
\hline & West coast & South coast & East coast \\
\hline $\begin{array}{l}\text { Beach slope }{ }^{*} \\
\left({ }^{\circ}\right)\end{array}$ & $32.8(5.6)$ & $24.3(7.6)$ & $19.8(4.8)$ \\
\hline $\begin{array}{l}\text { Compaction } \\
\left(\mathrm{N} \mathrm{cm}^{-2}\right)\end{array}$ & $145.7(39.1)$ & $135.9(90.2)$ & $95.0(55.1)$ \\
\hline$\%$ Water ${ }^{*}$ & $4.5(1.9)$ & $6.0(1.1)$ & $5.6(3.0)$ \\
\hline$\%$ Organics ${ }^{*}$ & $1.4(0.3)$ & $1.6(0.2)$ & $1.3(0.3)$ \\
\hline $\begin{array}{l}\text { Temperature } \\
\left({ }^{\circ} \mathrm{C}\right)^{\circ}\end{array}$ & $32.4(2.2)$ & $30.3(1.8)$ & $30.5(0.4)$ \\
\hline $\begin{array}{l}\text { Particle size } \\
(\%<425 \mu \mathrm{m})\end{array}$ & $70.4(10.8)$ & $26.5(20.0)$ & $79.1(11.4)$ \\
\hline Wave height $(\mathrm{m})^{\mathrm{a}}$ & 0.29 & 0.56 & 0.85 \\
\hline $\begin{array}{l}\text { Wave energy } \\
\left(\mathrm{kJ} \mathrm{m}^{-1}\right)^{\mathrm{a}}\end{array}$ & 10.8 & 22.3 & 50.7 \\
\hline $\begin{array}{l}{ }^{a} \text { Data from Halcr } \\
\text { Conservation Proje }\end{array}$ & $\begin{array}{l}\text { ow Caribbear } \\
\text { ect (1984) }\end{array}$ & n Ltd (1981) & and Coastal \\
\hline
\end{tabular}

ured. However, only for beach slope, wave height and wave energy do the values either directly or inversely reflect the distribution of hawksbill nests on coasts i.e. west $>$ south $>$ east (Table 2). The variation in wave height and wave energy between coasts is a consequence of the prevailing wind direction in Barbados, which is east to northeast. Thus the north and east coasts are the windward (exposed coasts), the south coast is less exposed, and the west coast is the leeward (protected coast). The data therefore suggest that hawksbills prefer to nest on beaches that are less exposed to wave impact and/or beaches of relatively steep slope.

\section{Variation within coasts}

The roles of distance inland of high tide mark, elevation above mean sea level and vegetation in determining the location of hawksbill nests on beaches were investigated. Frequency distributions of nests around the variables distance inland of high tide mark and elevation above mean sea level are shown in Fig. 2. Hawksbill nests occur between 3 and $22.5 \mathrm{~m}$ inland of the high tide mark (mean $8 \mathrm{~m}$ ), and at elevations above mean sea level of between 0.3 and $1.8 \mathrm{~m}$ (mean $1.11 \mathrm{~m}$ ). Nests are more normally distributed and have less spread around mean elevation than around mean distance inland of high tide mark (Fig. 2), suggesting that hawksbills are more sensitive to elevation than to distance from high tide mark when selecting nest sites.

Distance inland of high tide mark and elevation of nests above mean sea level are shown separately for nests on the west, south and east coasts in Table 3. Elevations of nests above mean sea level did not differ significantly between coasts, but hawksbills nested further from the high tide mark on the less steep east coast beaches than on the steeper south coast and west coast beaches (Table 3; see Table 2 for beach slopes). This suggests that hawksbills attempt to control nest elevation by changing the distance they travel inland on beaches of different slopes. This again indicates that elevation of nests is an important aspect of nest site selection in hawksbills.

On beaches with vegetation ( $\mathrm{n}=17$; typically sea grape Coccoloba uvifera and goat's foot yam Ipomoea 

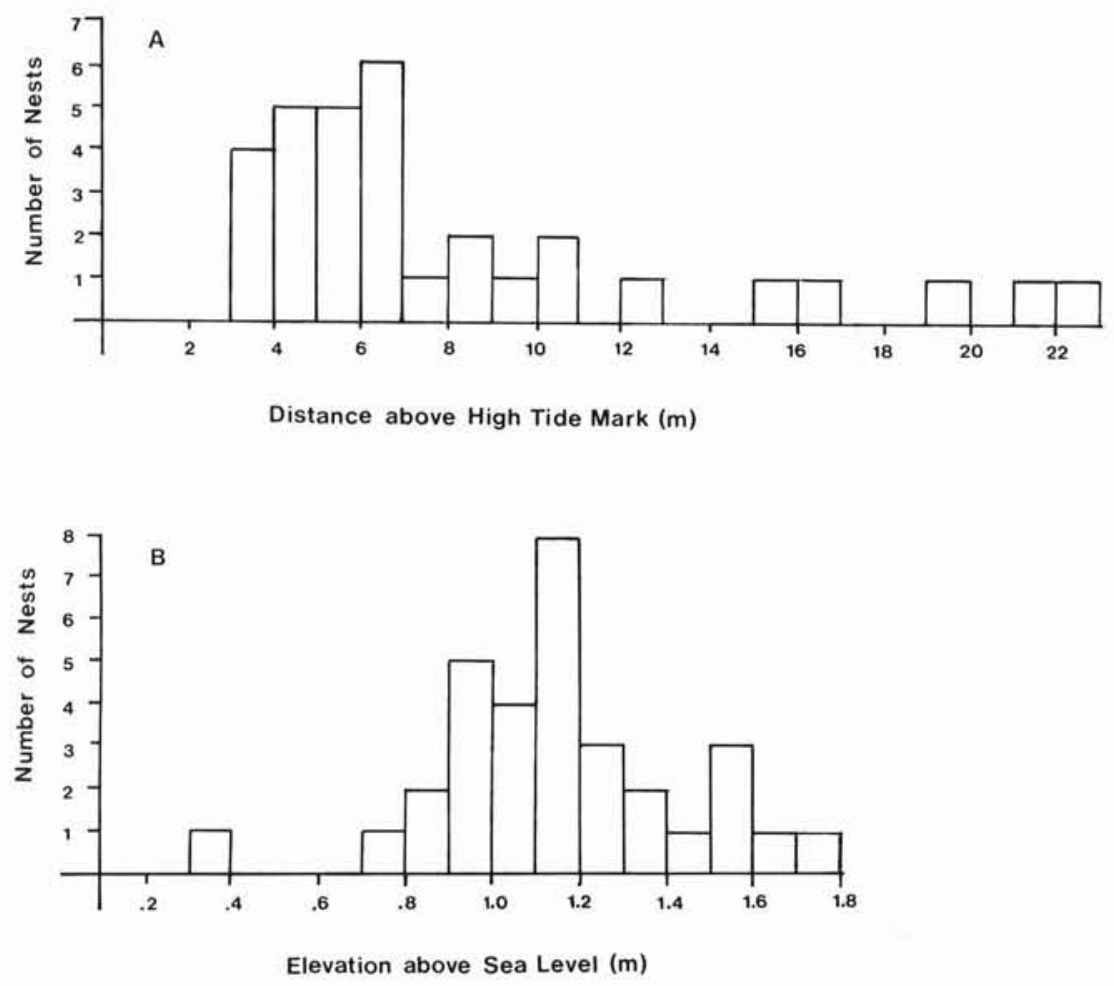

Fig. 2. Distribution of hawksbill nests. (A) Distance above (inland of) high tide mark (m); (B) elevation above mean sea level (m)

Table 3. Eretmochelys imbricata. Location of hawksbill nests on the west, south and east coasts. Means (standard deviations). 'Significant differences between coasts (KruskalWallis; $\mathrm{p}<0.05$ )

\section{West coast South coast East coast}

Distance of nest inland of high tide mark $(\mathrm{m})^{*}$ $6.15(4.28) \quad 8.55(5.20) \quad 10.81(7.00)$

Elevation of nest above mean sea level (m)

$1.05(0.29) \quad 1.18(0.17)$ $1.10(0.46)$

pes-caprae) and on which females therefore had the option of nesting in vegetation or away from it, significantly more females nested amidst vegetation $\left(\chi^{2}{ }_{c}=9.9\right.$, $\mathrm{p}<0.05$ ). This suggests that the distribution of vegetation may influence the location of hawksbill nests.

\section{Nest success}

Nest success can be defined as the number of hatchlings that emerge from a nest. As such, it has 2 components - number of eggs laid (clutch size) and percentage of eggs laid that emerge from the nest (emergence success). Emergence success itself has 2 components hatching success ( $\%$ of eggs that hatched) and escape success ( $\%$ of hatchlings that escape from the nest).
Nest success, clutch size, emergence success, hatching success and escape success for the 32 hawksbill nests studied in Barbados are shown in Table 4. Nest success was lowest on the east coast, but differed little between west and south coasts. The low nest success on the east coast may be due both to a smaller clutch size and a lower emergence success on that coast (Table 4). The lower emergence success results primarily from low hatching success, which in turn is due to a high percentage of undeveloped eggs in east coast nests (Table 4). The results tentatively suggest that nest success is lowest on the coast least preferred by hawks-

Table 4. Eretmochelys imbricata. Components of nest success of 32 hawksbill nests around Barbados. Means (standard deviations)

\begin{tabular}{|c|c|c|c|c|}
\hline & $\begin{array}{l}\text { West } \\
\text { coast }\end{array}$ & $\begin{array}{l}\text { South } \\
\text { coast }\end{array}$ & $\begin{array}{l}\text { East } \\
\text { coast }\end{array}$ & $\begin{array}{c}\text { All } \\
\text { coasts }\end{array}$ \\
\hline Nest success ${ }^{a}$ & 101.1 & 98.1 & 76.0 & $94.9(42.7)$ \\
\hline Clutch size & 133.5 & 134.0 & 121.0 & $127.0(30.3)$ \\
\hline$\%$ Emergence $^{\mathrm{b}}$ & 79.1 & 73.9 & 70.9 & $75.5(29.0)$ \\
\hline$\%$ Hatching ${ }^{c}$ & 89.1 & 85.6 & 72.1 & $84.5(19.8)$ \\
\hline$\%$ Undeveloped ${ }^{\mathrm{d}}$ & 8.2 & 9.2 & 26.1 & $11.9(17.2)$ \\
\hline$\%$ Dead embryos ${ }^{\mathrm{e}}$ & 3.2 & 6.6 & 2.4 & $4.4(11.2)$ \\
\hline$\%$ Escape $^{f}$ & 89.1 & 85.9 & 85.3 & $86.5(29.6)$ \\
\hline \multicolumn{5}{|c|}{$\begin{array}{l}{ }^{a} \text { No. of hatchlings that emerge from a nest; }{ }^{b} \% \text { laid that } \\
\text { emerged from a nest; }{ }^{c} \% \text { laid that hatch; }{ }^{d} \% \text { laid that } \\
\text { were undeveloped; }{ }^{e} \% \text { laid that died as embryos; }{ }^{1} \% \\
\text { hatched that escaped from the nest }\end{array}$} \\
\hline
\end{tabular}


bills (east coast). However, differences between coasts in nest success and its components were not statistically significant at our sample sizes.

\section{Effects of nest site characteristics on nest success}

Frequency distributions of nests on each of the environmental variables monitored indicated that number of nests was normally distributed with respect to 5 of the variables: elevation, temperature, \% organics, \% water and particle size. This may suggest that hawksbills prefer to nest near some mean value for these variables. Since the number of nests was symmetrical around the mean value of the environmental variable (e.g. Water Content), a new variable (Water Content 2) was derived to linearise the relationship between number of nests and the environmental variable. For nests with water contents less than or equal to the mean water content $(5.3 \%)$, Water Content 2 had the same value as Water Content. For nests with Water Content greater than $5.3 \%$, Water Content $2=2 \times(5.3)$ - Water Content (see Stamps \& Eason 1989). This linearisation procedure was repeated for elevation, temperature, \% organics and particle size.

To investigate effects of the 5 environmental variables on nest success and its components, parametric linear correlation analyses were performed between nest success and its components and the 5 linearised variables. Prior to the analyses, all components of nest success recorded as percentages were first normalised by arcsine transformation (Zar 1984). Nest success (number of hatchlings emerging from nest) was positively correlated with linearised elevation (Table 5), indicating that nests closest to mean elevation have highest nest success, with success declining for nests at higher and lower elevations. Nest success was not significantly correlated with any of the other linearised variables (i.e. particle size, \% organic, \% water, temperature; Table 5). Moreover, residuals from a linear regression analysis of nest success on linearised elevation were not correlated with any of the other linearised variables ( $\mathrm{p}>0.1$ in all cases), suggesting no effect of these variables on nest success even when effects of elevation are controlled.

Clutch size was not correlated with any environmental variables, suggesting that variation in nest success with elevation must arise through variation in emergence success ( $\%$ eggs laid that emerged as hatchlings). Emergence success was positively correlated with linearised elevation (Table 5), confirming that nests closest to mean elevation have highest emergence success, emergence success declining for nests at higher and lower elevations. Emergence success was not significantly correlated with any of the other linearised environmental variables (i.e. particle size, \% organics, \% water, temperature; Table 5), even when effects of elevation on emergence success were controlled by residual analysis ( $\mathrm{p}>0.1$ in all cases).

Both \% hatch and \% escape were positively correlated with linearised elevation (Table 5). This suggests that the higher emergence success from nests near mean elevation results both from a higher percentage of eggs hatching ( $\%$ hatch) and a higher percentage of hatchlings escaping from the nest following hatching ( $\%$ escape). The percentage of undeveloped eggs in a nest ( $\%$ undeveloped) was negatively correlated with linearised elevation (Table 5). This suggests that the lower hatching success observed in nests above and below mean elevation results primarily from a higher percentage of undeveloped eggs in such nests.

In contrast to the previous 5 environmental variables, the number of nests was not normally distributed around either compaction or vegetation. Consequently, effects of the latter variables on nest success were analysed differently. For compaction, the hypothesis was that increasing values would decrease nest success, but the 2 variables were not significantly correlated (Table 5). However, residuals from the regression of nest success on linearised elevation were negatively

Table 5. Pearson's correlation coefficients (r) between environmental variables characterising the nest, and nest success and its components. Values of elevation, particle size, \% organic, \% water and temperature were linearised prior to analysis (see text), and all components of nest success expressed as percentages were arcsine transformed. ${ }^{\circ}$ Significant correlation between the 2 variables $(\mathrm{p}<0.05)$

\begin{tabular}{|c|c|c|c|c|c|c|c|}
\hline & $\begin{array}{c}\text { Nest } \\
\text { success }\end{array}$ & $\begin{array}{l}\text { Clutch } \\
\text { size }\end{array}$ & $\%$ Emerge & $\%$ Hatch & $\%$ Escape & $\%$ Undeveloped & $\begin{array}{l}\% \text { Dead } \\
\text { embryos }\end{array}$ \\
\hline Elevation & $0.42^{\circ}$ & 0.01 & $0.36^{\circ}$ & $0.38^{*}$ & $0.38^{\circ}$ & $-0.51^{\circ}$ & 0.32 \\
\hline Particle size & -0.04 & 0.19 & -0.13 & -0.01 & -0.12 & 0.00 & 0.12 \\
\hline$\%$ Organic & 0.05 & -0.01 & 0.01 & 0.02 & -0.00 & -0.04 & -0.01 \\
\hline$\%$ Water & 0.30 & 0.31 & 0.16 & 0.13 & 0.10 & -0.12 & -0.12 \\
\hline Temperature & -0.31 & -0.12 & -0.29 & -0.23 & -0.21 & 0.18 & 0.16 \\
\hline Compaction & -0.24 & 0.16 & $-0.35^{\circ}$ & -0.05 & $-0.35^{\circ}$ & -0.11 & $0.48^{\circ}$ \\
\hline
\end{tabular}


correlated with compaction $(\mathrm{r}=-0.34, \mathrm{p}<0.05)$. This indicates that, when effects of elevation on nest success are controlled, higher nest success at lower compaction can be detected.

Of the 2 major components of nest success i.e. clutch size and emergence success, the former was not correlated with compaction but the latter was; indicating that emergence success decreases with increasing compaction (Table 5). The decrease in emergence success observed with increasing compaction is due both to an increase in the percentage of dead embryos in nests (\% dead embryos; Table 5) and a decrease in the percentage of hatchlings that escape from nests ( $\%$ escape; Table 5).

Females preferred to nest at sites with vegetation than sites without (see previous results). Nest sites with vegetation were significantly less compacted (mean $\left.94.7 \mathrm{~N} \mathrm{~cm}^{-2}\right)$ than non-vegetated sites $\left(165.2 \mathrm{~N} \mathrm{~cm}^{-2}\right.$; $\mathrm{t}=3.41, \mathrm{p}<0.002)$, and escape success was significantly higher from vegetated than non-vegetated nests (mean escape success at vegetated nests $=91.4 \%$; at non-vegetated nests $=82.5 \% ; \mathrm{t}=2.13, \mathrm{p}<0.05$; on arcsine transformed values). The fact that the higher escape success did not result in a significant difference in either nest success $(t=0.43, p>0.05$; on arcsine transformed values) or emergence success $(\mathrm{t}=1.04, \mathrm{p}>$ 0.05 ; on arcsine transformed values) between nests with vegetation and those without is presumably because of variation in other components of nest and emergence success that is unrelated to effects of vegetation.

\section{Effects of nest site on sex ratio}

All sexed hatchlings $(n=67)$ came from nests on the west and south coasts; 31 from the south and 36 from the west. In spite of the small sample size, there was a highly significant effect of coast on hatchling sex ratio; more males $(67.7 \%)$ were hatched from south coast nests and more females $(80.6 \%)$ from west coast nests $\left(\chi_{c}^{2}=14.8 ; p<0.001\right)$. West coast nest sites were significantly warmer $\left(32.4^{\circ} \mathrm{C}\right)$ than south coast nest sites $\left(30.3^{\circ} \mathrm{C} ; \mathrm{t}=2.65 ; \mathrm{p}<0.05\right)$. The data therefore suggest a temperature-dependent bias in sex ratio towards females at warmer temperatures and towards males at cooler temperatures. This is consistent with the pattern found in other marine turtles (Miller \& Limpus 1981, Yntema \& Mrosovsky 1982, Miller 1985).

\section{DISCUSSION}

Mean emergence success from hawksbill nests which were not destroyed during incubation was $75.7 \%$ in Barbados. This is lower than the values reported for undisturbed hawksbill nests in Costa Rica (91.6\%; Bjorndal et al. 1985), the US Virgin Islands (90.1\%; Small 1982), the Solomon Islands (84.3\%; McKeown 1977), and Australia (91.0\%; Limpus 1980). Only in Puerto Rico was emergence success lower than in Barbados (67.1\%; Olson 1985). In spite of the low emergence success, nest success in Puerto Rico (105.8) was higher than in Barbados (94.9), because mean clutch size was larger (Puerto Rico 157.6; Barbados 133.5).

Most hawksbill nesting in Barbados occurred on protected west coast beaches, less on the more exposed south coast beaches and least on the fully exposed east coast beaches. Hawksbills may prefer the more protected beaches because of the mechanical difficulties and energetic costs of moving onto and off beaches characterised by heavy wave action. In addition, west coast beaches have steeper slopes than south and east coast beaches. Since hawksbills show preference for nesting at a particular elevation above sea level, females must travel further inland to nest on east coast than south and west coast beaches. This may increase both the energetic costs of nesting and the probability of capture. Moreover, hatchlings emerging on west coast beaches will have less far to travel and will be aided by the steeper beach slope, factors that will decrease both their energetic expenditure and their risk of predation. Whitmore \& Dutton (1985) have suggested that the large size of leatherback turtles relative to green turtles, and the slower speed of leatherback hatchlings, may make the length of the crawl on land more critical for leatherbacks than greens, and may partly explain the tendency for leatherbacks to nest closer to the sea than green turtles on shared nesting beaches in Suriname. Our data suggest that length of crawl may also be an important factor influencing nesting behaviour of hawksbills.

Apart from the disadvantages of difficult beach access and higher travel costs associated with east coast beaches, the number of hatchlings emerging from nests (nest success) was lowest on east coast beaches. This is primarily because of a high percentage of undeveloped eggs in east coast nests, but also because of a lower clutch size in these nests. The latter observation raises the possibility that clutch size may partly depend on beach characteristics i.e. hawksbills may produce larger clutches on preferred beaches. The fact that hawksbills prefer to nest on beaches where pre-hatching mortality is lower, and where the energetic costs and predation risks for both adults and hatchlings are probably lower, suggests that the nesting preference for the different beach types is adaptive.

Elevations of hawksbill nests above mean sea level did not differ significantly between coasts in Barbados, because females changed the distance they travelled 
inland on beaches of different slopes. This suggests that elevation is an important aspect of nest site selection in hawksbills. The observation that nest success is highest in nests closest to mean elevation and declines at higher and lower elevations suggests that the preference for a specific elevation is adaptive. Nest success was not correlated with either particle size, \% organics, $\%$ water or temperature. Precisely what abiotic characteristics of elevation are affecting nest success remains unclear. Clutch size was not correlated with any of the environmental variables, suggesting that the variation in nest success with elevation must arise through variation in emergence success. The variation in emergence success with elevation results from variation in both hatching success and escape success.

When effects of elevation on nest success were controlled, nest success decreased with increasing compaction. Moreover, emergence success decreased with increasing compaction. This was due both to an increase in the percentage of dead embryos in nests (late pre-hatching mortality) and a decrease in escape success (post-hatching mortality). Both the late prehatching mortality and the post-hatching mortality may be due to an increasing probability of suffocation with increasing compaction. The post-hatching mortality may also be due to exhaustion resulting from unsuccessful attempts by hatchlings to dig out of nests.

Hawksbills in Barbados preferred to nest at sites with vegetation than at those without. This preference has previously been documented (Mortimer 1982, Richardson et al. 1989), but the consequences of the preference for nest success have not been investigated. Nest sites with vegetation were less compacted than those without, perhaps because of the loosening effect of rootlets growing through the sand. Consistent with this, vegetated sites had higher escape success than non-vegetated sites.

It is now well accepted that beach lighting accompanying coastal development can cause disorientation of hatchlings and lead to considerable hatchling mortality following emergence from the nest (see Raymond 1984). Our results suggest that several other phenomena associated with coastal development in countries such as Barbados may reduce nest success of hawksbills and may jeopardise the long-term viability of hawksbill populations. Buildings and guard walls too close to the sea, as well as property-protecting boulders and gabions, increasingly may force hawksbills to nest at lower than preferred beach elevations, thereby leading to reduced nest success.

Nesting at reduced elevations may also affect hatchling sex ratio. Nest site temperatures are lower at lower beach elevations (Horrocks unpubl.). Present results suggest that cooler beaches (south coast) produce malebiased sex ratios, and warmer beaches (west coast) produce female-biased ratios. Consequently, nesting at lower elevations may ultimately produce population sex ratios skewed towards males. Sex determination is known to be temperature-dependent in several marine turtles; in all cases, cooler temperatures producing male-biased clutches (Mrosovsky \& Yntema 1980, Limpus et al. 1983). Limpus et al. (1983) observed that in Australia, island beaches which face north are warmer than those which face south. They suggested that particular beaches could therefore be female-producing or male-producing and that development might be interfering with female-producing beaches in Australia. In Barbados, west coast beaches are female-producing and south coast beaches male-producing. Being forced to nest at low elevations could therefore transform female-producing beaches into male-producing beaches in Barbados and other islands of the Caribbean.

A second aspect of coastal development that may reduce hawksbill nest success is the heavier recreational use of beaches. A consequence of this is increased sand compaction which reduces hawksbill nest success by increasing late pre-hatching egg mortality and by decreasing escape success of hatchlings. The increased compaction resulting from heavier beach use may be aggravated by another characteristic of coastal development - the large-scale clearance of beach vegetation, a practice conducted in the Caribbean to make beaches appear wider and aesthetically pleasing. Our results suggest that hawksbills prefer to nest at vegetated sites, that vegetated sites are less compacted, and that, as a consequence, nests at vegetated sites have higher escape success than non-vegetated sites.

Tourism in Barbados and the eastern Caribbean is growing rapidly. It is unlikely that legislation will be passed solely for the protection of turtles at the expense of a major revenue-earning, employment-generating industry. Without such legislation, the future of hawksbill populations in Barbados and the eastern Caribbean will be heavily dependent on the activities of nongovernmental organisations, the interest and concern of the public and the goodwill of owners and managers of beachfront properties.

Acknowledgements. We thank N. Drayton, F. Goodfellow, D. Green, L. Vermeer, and P. Ward for assistance with data collection, and W. Hunte for comments on the manuscript.

\section{LITERATURE CITED}

Atherley, K. (1987). Analysis of beach change on the Barbados coast. Coastal Conservation Project Unit, Government of Barbados, Bridgetown, Barbados, p. 1-36

Bjorndal, K. A., Carr, A., Meylan, A., Mortimer, J. A. (1985). Reproductive biology of the hawksbill Eretmochelys imbricata at Tortuguero, Costa Rica, with notes on the ecology of the species in the Caribbean. Biol. Cons. 34: 353-368 
Carr, A., Stancyk, S. (1975). Observations on the ecology and survival outlook of the hawksbill sea turtle. Biol. Cons. 8: 161-172

Coastal Conservation Project (1984). Diagnostic survey, Vol. 3. Section 9: Waves. Proctor \& Redfern International/Government of Barbados/Inter-American Development Bank, p. $1-59$

Halcrow Caribbean Ltd (1981). Wave power study for Barbados. Prepared for Ministry of Finance and Planning, Government of Barbados, p. 1-79

Horrocks, J. A., Oxenford, H. A., Willoughby, S. (1989). Nest site location and clutch mortality of hawksbill turtles (Eretmochelys imbricata) in Barbados, West Indies. In: Eckert, S. A., Eckert, K. L., Richardson, T. H. (Compilers) Proc. of the Ninth Ann. Workshop on Sea Turtle Cons. Biol., NOAA Technical Memorandum NMFS-SEFC-232, p. 239-241

Limpus, C. (1980). Observations on the hawksbill turtle (Eretmochelys imbricata) nesting along the Great Barrier Reef. Herpetol. 36: 265-271

Limpus, C. J., Reed, P., Miller, J. D. (1983). Islands and turtles: the influence of choice of nesting beach on sex ratio. In: Baker, J. T., Carter, R. M., Sammarco, P. W., Stark, K. P. (eds.) Proc. Inaugural Great Barrier Reef Conference, Townsville. JCU, Townsville, p. 397-402

McKeown, A. (1977). Marine turtles of the Solomon Islands. Ministry of Natural Resources, Fisheries Division, Honiara, p. $1-47$

Miller, J. D. (1985). Embryology of marine turtles. In: Gans, C., Billett, F., Maderson, P. F. A. (eds.) Biology of the Reptilia, Vol. 14. Wiley, New York, p. 269-328

Miller, J. D., Limpus, C. (1981). Incubation period and sexual differentiation in the green turtle, Chelonia mydas L. In: Banks, C. B., Martin, A. A. (eds.) Proc. of the Melbourne Herpetol. Symp. Zoological Board of Victoria, Parkville, p. 66-73

Mortimer, J. (1982). Factors influencing beach selection by nesting sea turtles. In: Bjorndal, K. A. (ed.) Biology and conservation of sea turtles. Smithsonian, Washington, D.C., p. $45-51$

Mrosovsky, N., Yntema, C. L. (1980). Temperature-dependence of sexual differentiation in sea turtles: implications for conservation practices. Biol. Cons. 18, 271-280

This article was submitted to the editor
Olson, M. H. (1985). Population characteristics of the hawksbill turtle (Eretmochelys imbricata) on Mona Island, Puerto Rico: a case study of US Endangered Species Act. Proc. Fifth Int. Coral Reef Congress, Tahiti, Vol. 5, p. 475-480

Raymond, P. W. (1984). Sea turtle hatchling disorientation and artificial beachfront lighting. Center for Environmental Education, Washington, D.C., p. 1-72

Richardson, J. I., Corliss, L. A., Ryder, C., Bell, R. (1989). Demographic patterns of Caribbean hawksbills, Jumby Bay, Antigua. In: Eckert, S. A., Eckert, K. L., Richardson, T. H. (Compilers). Proc. of the Ninth Ann. Workshop on Sea Turtle Conservation and Biology. NOAA Technical Memorandum NMFS-SEFC-232, p. 253-256

Ryder, C., Richardson, J. I., Corliss, L. A., Bell, R. (1989). Habitat preference and beach management for nesting hawksbills, Jumby Bay, Antigua, West Indies. In: Eckert, S. A., Eckert, K. L., Richardson, T. H. (Compilers). Proc. of the Ninth Ann. Workshop and Sea Turtle Conservation and Biology. NOAA Technical Memorandum NMFSSEFC-232, p. 263-266

Small, V. (1982). Sea turtle nesting at Virgin Islands National Park and Buck Island Reef National Monument, 1980 and 1981. US Department of the Interior, National Park Service Research/Resources Management Report, SER-61

Stamps, J. A., Eason, P. K. (1989). Relationships between spacing behaviour and growth rates: a field study of lizard feeding territories. Behav. Ecol. Sociobiol. 25: 99-107

Whitmore, C. P., Dutton, P. H. (1985). Infertility, embryonic mortality and nest-size selection in leatherback and green sea turtles in Suriname. Biol. Cons. 34: 251-272

Witzell, W. N. (1983). Synopsis of biological data on the hawksbill turtle Eretmochelys imbricata (Linnaeus, 1766). FAO Fisheries Synop. 137, Rome

Yntema, G. L., Mrosovsky, N. (1980). Sexual differentiation in hatchling loggerhead (Caretta caretta) incubated at different controlled temperatures. Herpetol. 36: 33-36

Yntema, C. L., Mrosovsky, N. (1982). Critical periods and pivotal temperatures for sexual differentiation in loggerhead sea turtles. Can. J. Zool. 60: 1012-1016

Zar, J. H. (1984). Biostatistical analysis. Prentice-Hall, New Jersey

Manuscript first received: May 31, 1990

Revised version accepted: September 12, 1990 